\title{
Influence of Educational Welfare Measures with References to Government and Aided School Students in Chennai
}

\author{
M. Kavitha, S. Navin Kumar
}

\begin{abstract}
Now a day Education is a great extent paid for as well as for the most part directed by non-benefit organizations or governmental bodies. This situation has grown slowly as well as is currently underestimated so much that little express consideration is any more extended coordinated to the explanations behind the unique treatment of education even in nations that are dominatingly free endeavor in theory as well as association. The outcome has been an aimless expansion of governmental obligation. In this paper, the author has examined the factors impact of educational welfare measures with references to government and aided school understudies in Chennai.
\end{abstract}

Keywords: Government, School, Educational Welfare, Student and Education.

\section{INTRODUCTION}

$\mathrm{T}$ he government sets out to enhance the educational quality and give all welfare advantages to the understudies has allotted a measure of Rs.62,583.49 crores to the School Education Department from 2011-2012 to 2014-2015. This is the most astounding designation given in the monetary allowance to any department.

The governments activity in authorizing 71,708 designating as well as teaching posts 53,288 educators in the previous three years has not just improved the educational quality yet has additionally brought about the memorable accomplishment of pass level of $90.7 \%$ in the tenth Standard as well as $90.6 \%$ in the twelfth board assessment held in 2014. There has been an exceptional execution by the students concentrating in government schools. The exhibition of students in twelfth standard in government schools has expanded from $79 \%$ in 2013 to $84 \%$ in 2014 . Essentially, the presentation of students in tenth standard in government schools has expanded from $80 \%$ in 2013 to $84 \%$ in 2014. Without precedent for the historical backdrop of Tamil Nadu kids concentrating in government, schools have gotten the main, second and third position. This significant achievement has been conceivable because of the all-encompassing improvement of the School Education

Revised Manuscript Received on December 05, 2019.

* Correspondence Author

Dr. M. KAvitha* ${ }^{*}$ Assistant Professor, P.G. and Research Department of Commerce, Guru Nanak College (Autonomous), Chennai, India.

S. Navin Kumar, Research Scholar, P.G. and Research Department of Commerce, Guru Nanak College (Autonomous), Chennai, India.
Department under the capable direction of the government.

The government has achieved a decent development in the education area by concentrating on the educational quality and foundation in schools. Further to empower children and girl students in educationally in reverse obstructs an extra measure of Rs.141.91 Crores has been liberally given by the government to finish the long-pending works of model schools and girl's hostels. The governments with them worry to give imperative toilet facilities in the government schools has requested for doing the needful. 34,796 schools have been given toilet facilities as well as 34,193 schools have been given drinking water facilities in this manner guaranteeing $100 \%$ inclusion of drinking water and toilets offices in all the government schools.

An exceptional program of giving vehicle and escort facility has been acquainted with give access to children living in remote as well as hilly zones. The Government of Tamil Nadu has additionally made arrangement for teaching the children of transient workers in their mother language. The Government has started an inventive program for giving access by Connecting Class Rooms from an asset centre at the region level to the remote territories.

The Government with a respectable goal of giving free and necessary education to all children and to urge them to finish their schooling effortlessly had reported certain welfare plans, which are being executed effectively from 2018-2019 onward.

i. The School Education Department has been allotted nearly Rs.27,205.88 crore in the Budget 2018-19 for providing 'Quality education for all'. The conscious undertakings, upheld by such enormous budgetary allotments, taken by instructive visionaries in Tamil Nadu to make quality education open to each segment of the general public, have yielded rich profits as far as structure an energetic society.

ii. The educationists and other partners have appropriately understood that the following intelligent advance is to make education, kid driven. The idea of universalization of education with a goal of social, economic and cultural strengthening has from the start been the top need of the policy makers. 
iii. Push on bringing the girl children into the standard of education has prompted women strengthening in the general public. All types of social mistreatment dependent on caste, statement of faith, sexual orientation and societal position have been bit by bit destroyed by quality education.

iv. Quick walks on the wildernesses of Technology as well as Science have opened up numerous roads for the student network to spread their wings and demonstrate their grit. In this specific situation, it has turned out to be basic to tune redesign the abilities of students to the rising needs. The endeavors taken by the Government toward this path have immensely improved the openings for work to lakhs of individuals, in this manner raising their way of life.

$\mathrm{v}$. The information and knowledge period has brought forth more up to date experiences into the educational administration. The effect of education in the economic upliftment of people specifically and the nation when all is said in done has been acknowledged by all concerned. The policy makers have likewise understood the need to mix new ideas in scattering of education, equivalent with the developing patterns. Utilization of information and communications technology (ICT) in educating and learning is being utilized to the furthest reaches.

vi. Access, foundation, accessibility of educators, quality substance, limit working of teachers, computerization and digitization of the substance and class room procedure have been the essential center territories of the School Education Department.

vii. Push on making educational framework and different aspects in the ongoing past have improved access and moderateness towards education all things considered. A measure of Rs.721.09 crore, over the most recent two years has been spent for providing school structures, extra homerooms, toilets, drinking water offices, compound divider, kitchen sheds, and uncommon framework offices for Children with Special Needs (CWSN) and so forth.

viii. So as to improve access and maintenance of students in schools, the Government has been proceeding with welfare plans for students for example, four arrangements of uniform, woolen sweaters for children concentrating in hill territories, laptop, exceptional money motivating force to diminish dropouts, school sack, geometry box, footwear, shading pencils, pastels, map book, reading material, notebooks, cycle, transport pass, early afternoon dinner and budgetary help to children who have lost their bread winning guardians. A total of Rs.1967.47 crore has been reserved for these welfare plans for the year 2018-19.

ix. The tireless endeavors taken by the Government on different viewpoints have brought about increment in Net Enrollment Rate at the essential level from 99.63 in 2011-12 to 99.86 in 2017-18, at the upper essential level from 98.88 in 2011-12 to 99.22 in 2017-18. There has been considerable lessening in the dropout rates.

$\mathrm{x}$. The center has now moved towards accomplishment of quality education. At present, the accentuation is on progress of extension alongside perfection in conveyance of education. The State is excited about making the educational administration, a healthy procedure for citizens. xi. The Government has taken numerous activities in the ongoing past to improve learning condition and educational quality. A portion of these activities are; the educational program and schedule have been overhauled after a hole of over 12 years for 11 as well as 12 standard and over 7 years for norms 1 to 10 ; crafted by composing course reading has additionally picked up energy; the ranking framework dependent on the imprints verified by the students has been canceled to check unfortunate challenge among schools; Board assessment for class 11 has been acquainted with manufacture limit of students to confront any focused assessment; presentation of ICT in schools has been taken up in a major manner by setting up hi-tech labs in all Government high and higher secondary schools and shrewd classes in middle and primary schools.

xii. The premise of all such approach activities in Tamil $\mathrm{Nadu}$ is well-settled in recorded establishments and thoughtful points of view.

The policy note for the year 2018-19 is thus exhibited in the sincere any desire for serving the reason for education and encouraging a quantum jump in its advancement.

\section{REVIEW OF LITERATURE}

Concentrate on education policy execution, its definition, determinants and procedures. It means to explain what executing strategies include in complex education frameworks to help policy work (Romane Viennet, et al., 2017), expanding on the writing and nation models. A presentation digs into the explanations for the need to refresh the idea of education policy execution, which is characterized as a deliberate and multidirectional change procedure expecting to incorporate a particular policy and which influences education framework on a few levels.

The point of early intercession is to enhance student's learning by: a) tending to formative issues; and b) using their qualities to go around their troubles and in this manner improve their prosperity and working. Distinguishing the proper components to impact these targets is not direct. A considerable lot of the early intercession studies are liable to methodological confinements (see Jordan, James and Murray, 1998). Be that as it may, where a reasonable proof based intercession has been actualized constructive outcomes are obvious. For instance Burchinal, et al. (2000) inspected the nature of focus based day care for 89 African American children. Results demonstrated that higher quality child care was identified with proportions of psychological improvement, language advancement and relational abilities even in the wake of altering for chosen children and family attributes. Prescribed degrees of children grown-up proportions and teacher preparing were additionally key components (Burchinal, et al., 2000).

The field of comprehensive education in the Indian setting with a point, to clarify the alternate points of view in its understandings and different clashes in its conceptualization,

Published By.

Blue Eyes Intelligence Engineering 
while recognizing significant gaps (NidhiSingal, 2007).

Reid (1988) featured a 'professional dichotomy' inside the EWS. It was thought to begin mostly from the fluctuated preparing foundations of numerous EWOs - some were completely untrained, others halfway, while the rest of full scholarly or potentially proficient capabilities. At the time, Reid called for national concurrences on the substance and structure of beginning and in-administration instructional classes, without which he felt that 'very numerous EWOs are

working with signals on, in light of the fact that they know no better'. All the more as of late, Collins (1998) again attracted regard for this issue and announced that most of EWS representatives had no pertinent preparing in teaching, social work or other related callings.

Without government an order concerning administration association, staffing or capabilities, EWSs will in general reflect nearby needs and neighborhood rehearses (Collins, 1998). In one examination, the everyday activities of the EWS were explored utilizing a postal overview (Halford, referred to in Collins, 1998). A scope of exercises was distinguished. Respondents discussed home visits to meeting guardians and children, advising pupils, working cooperatively with instructors, contact with different organizations, giving welfare rights guidance to guardians, and running gathering work sessions. The job of the EWS can incorporate numerous and different exercises and mediation might be focused at a scope of beneficiaries, not simply students.

\section{SIGNIFICANCE OF THE STUDY}

The study gains importance from the students has to attain a knowledge based Human Development; the State must ensure that everyone gets Quality Education without any barrier. Under this backdrop the present study aims at assessing the influence of educational welfare measures with references to government $\&$ aided school students.

\section{OBJECTIVES OF STUDY}

The study aims at studying the influence of educational welfare measures with references to government \& aided school students. It further aims to assess the performance of students on the basis of their educational welfare measures.

$>$ Providing quality education in all government school students

$>$ Implementation of RTE Act, 2009

$>$ Providing an inclusive environment in schools conducive to Children With Special Needs (CWSN) and student belonging to weaker section and disadvantaged group

$>$ Improving reading, speaking, listening, writing as well as arithmetic skills of the student

$>$ Enriching the knowledge of the student in scholastic and co-scholastic areas

\section{RESEARCH METHODOLOGY}

The research was limited to the influence of educational welfare measures with references to government and aided school students. A structured questionnaire was developed using parameters identified from previous surveys.

Population: The response rate was 85 percentages and the descriptive data for 100 respondents is presented below.

Research Tool: ANOVA (Analysis of Variance) and SEM (Structural Equation Modeling)

\section{Hypothesis}

$\mathrm{H}_{1 \cdot 1}$ : There is no significant difference between age and the Basic Freebies.

$\mathrm{H}_{1.2}$ : There is no significant difference between age and the Freebies Usefulness.

$\mathrm{H}_{1.3}$ : There is no significant difference between age and the Future expectations in Education.

$\mathrm{H}_{1.4}$ : There is no significant difference between age and the Awareness.

$\mathrm{H}_{1.5}$ : There is no significant difference between age and the Educational Welfare.

\section{RESEARCH QUESTION}

Research Question 1 (RQ1) : Does the variables viz. Basic Freebies, Freebies Usefulness, Future expectations in education impact Awareness?

Research Question 2 (RQ2) : Does the variables viz. Awareness impact Educational Welfare?

\section{ANALYSIS AND INTERPRETATION}

This chapter essentially presents the results and analysis of the information gathered from the educational welfare measures with references to government and aided schools in Chennai. The data are grouped appropriately to carry out the meaningful analysis.

In the initial segment, it is proposed to exhibit in detail, the view of the respondents on different parts the educational welfare measures with references to government and aided schools in Chennai factors like Basic Freebies, Freebies Usefulness, and Future expectations. The last part of the section has focused on testing of speculation. The entire research hypotheses which were formulated are tested using SEM.

\section{A. Conceptual Frame work}

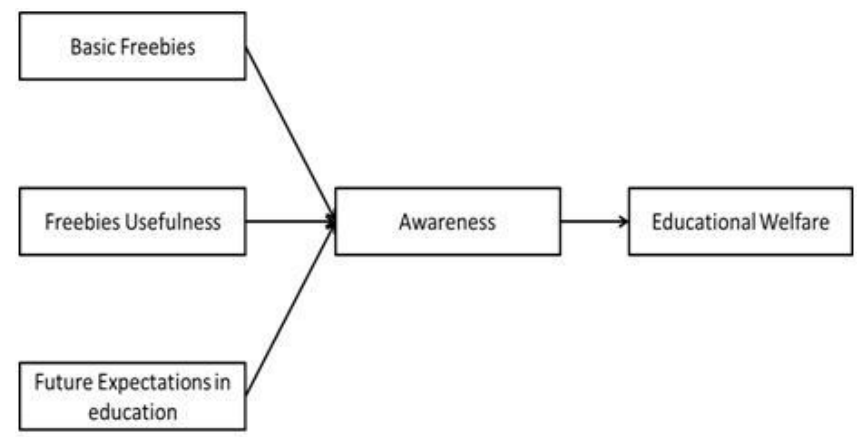

\section{Structural Equation Modelling (Sem)}

Structural equation modeling is a multivariate factual analysis system that is

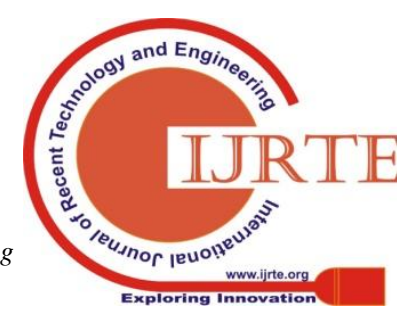


utilized to break down structural connections. This technique is favored by the researchers since it appraises the numerous and interrelated reliance in a solitary analysis.

\section{Observed, endogenous variables}

\section{Awareness}

Educational Welfare

\section{Observed, exogenous variables}

Basic Freebies

Freebies Usefulness

Future expectations in Education

\section{Unobserved, exogenous variables}

e1 (error in the term of Awareness)

e2 (error in the term of Educational Welfare)

Variable counts (Group number 1)

Number of variables in your model: 8

Number of observed variables: 6

Number of unobserved variables: 2

Number of exogenous variables: 6

Number of endogenous variables: 2

Major Model Fit Indices Summary

\begin{tabular}{|l|l|l|}
\hline Parameters & $\begin{array}{l}\text { Acceptable values } \\
\text { for Good Fit }\end{array}$ & $\begin{array}{l}\text { Research Model } \\
\text { Values }\end{array}$ \\
\hline GFI & $>0.9$ & 0.964 \\
\hline AGFI & $>0.9$ & 0.976 \\
\hline CFI & $>0.9$ & 0.920 \\
\hline RMSEA & $<0.06$ & 0.01 \\
\hline RMR & $<0.08$ & 0.06 \\
\hline & &
\end{tabular}

Interpretation: The Goodness of Fit index (GFI) value was 0.964, Adjusted Goodness of Fit Index (AGFI) value was 0.976 and Comparative Fit index (CFI) value was 0.920 . The values all were greater than 0.9 indicating a very good fit. It was found that Root Mean Score Error of Approximation (RMSEA) value was 0.01 (lesser than 0.06) and Root Mean Square Residual (RMR) value was 0.06 (lesser than 0.08).

\section{Discussion}

The result in the above table shows that the model fit is good for the research analysis.

One Way Analysis of Variance of the Age, Basic Freebies, Freebies Usefulness, Future expectations in Education, Awareness, and Educational Welfare

$\mathrm{H}_{1.1}$ : There is no significant difference between age and the Basic Freebies.

$\mathrm{H}_{1.2}$ : There is no significant difference between age and the Freebies Usefulness.
$\mathrm{H}_{1.3}$ : There is no significant difference between age and the Future expectations in Education.

$\mathrm{H}_{1.4}$ : There is no significant difference between age and the Awareness.

$\mathrm{H}_{1.5}$ : There is no significant difference between age and the Educational Welfare.

Table - ANOVA

\begin{tabular}{|c|c|c|c|c|c|c|}
\hline \multicolumn{2}{|l|}{ Variance } & \multirow{2}{*}{\begin{tabular}{|l} 
Sum of Squares \\
50.878 \\
\end{tabular}} & \multirow{2}{*}{ Df } & \multirow{2}{*}{\begin{tabular}{|l} 
Mean Square \\
16.959 \\
\end{tabular}} & \multirow{4}{*}{$\begin{array}{l}f \\
.455\end{array}$} & \multirow{4}{*}{\begin{tabular}{|l} 
Sig \\
.714
\end{tabular}} \\
\hline \multirow{3}{*}{ Basic Freebies } & Between Groups & & & & & \\
\hline & Within Groups & 12419.199 & 97 & \multirow[t]{2}{*}{37.295} & & \\
\hline & Total & 12470.077 & 100 & & & \\
\hline \multirow{3}{*}{ Freebies Usefulness } & Between Groups & 56.288 & 3 & 18.763 & \multirow{3}{*}{2.567} & \multirow{3}{*}{$.050^{*}$} \\
\hline & Within Groups & 11024.329 & 97 & \multirow[t]{2}{*}{33.106} & & \\
\hline & Total & 11732.445 & 100 & & & \\
\hline \multirow{3}{*}{$\begin{array}{l}\text { Future expectations in } \\
\text { Education }\end{array}$} & Between Groups & 60,337 & 3 & 20.112 & \multirow{3}{*}{2.871} & \multirow{3}{*}{$.036^{*}$} \\
\hline & Within Groups & 7686.428 & 97 & \multirow[t]{2}{*}{23.082} & & \\
\hline & Total & 7746.766 & 100 & & & \\
\hline \multirow{3}{*}{ Awareness } & Between Groups & 83.054 & 3 & 27.685 & \multirow{3}{*}{3.253} & \multirow{3}{*}{$.021^{* *}$} \\
\hline & Within Groups & 7357.617 & 97 & \multirow[t]{2}{*}{22,095} & & \\
\hline & Total & 7440.671 & 100 & & & \\
\hline \multirow{3}{*}{ Educational Welfare } & Between Groups & 51.465 & 3 & 17.155 & \multirow{3}{*}{.479} & \multirow{3}{*}{.697} \\
\hline & Within Groups & 11936.826 & 97 & \multirow[t]{2}{*}{35.846} & & \\
\hline & Total & 11988.291 & 100 & & & \\
\hline
\end{tabular}

“** Significant at 1\% level * Significant at 5\% level”

Analysis: It can be seen from Table 1 that Null Hypotheses $\mathrm{H} 1.2, \mathrm{H} 1.3$, and H1.4are rejected as the $\mathrm{p}$ value is lesser than 0.05. All other remaining null hypotheses are accepted.

Discussion: There is no significant difference between age and the Basic Freebies. There is significant difference between age and the Freebies Usefulness. There is significant difference between age and the Future expectations in education. There is significant difference between age and the awareness. There is no significant difference between age and the Educational Welfare.

\section{SUGGESTION}

Educational Welfare has to be meant for improving quality of life in school students and not alone in academic.

To acknowledge openings that advance correspondence, improve the person's social position.

The influence of Educational Welfare seen highly among government aided school students may be increased among students to develop their skills.

The Government of Tamil Nadu is committed to provide quality education for all.

Published By: 
Improving speaking, reading,listening, writing as well as arithmetic skills of the school students.

Enriching the knowledge of the students in scholastic and co-scholastic areas.

Give a coordinated and far reaching educational program approach that fuses fair open doors for all students to improve their own and others' prosperity through their day by day learning encounters.

\section{CONCLUSION}

This study will enable the education welfare to get aware of government and aided school students. Samagra Shiksha Abhiyan supplements the endeavors and activities of the Department of School Education in accomplishing the destinations. By actualizing a progression of plans grounded on quality, value and reasonableness, it endeavors to make empowering condition for educating and learning in Government schools in chennai and to advance information, qualities and abilities of students.

This is a small step to make the students of the government schools to critically think about the educational welfares. To achieve the goals of every government school students should know about the educational welfares, schemes, and policies. This will ultimately lead to a better educational welfare in their future.

\section{REFERENCES}

1. Australian Association of Social Workers. (2004). Continuing professional educational policy. Retrieved December 2, 2006 from http://www.aasw.asn.au/adobe/profdev/CPE_policy_2006pdf.

2. Burchinal, M.R., Roberts, J.E., Riggins, R., Zeisel, S.A., Neebe, E. and Bryant, D. (2000).Relating quality of center-based child care to early cognitive and language development longitudinally. Child Development, 71, 339-357.

3. Council on Social Work Education.(2002). Educational policy and accreditation standards. Alexandria, VA: Author.

4. http://cms.tn.gov.in/sites/default/files/documents/sedu_e_pn_2014_15.pdf

5. http://cms.tn.gov.in/sites/default/files/documents/sedu_e_pn_2018_19.pdf

6. https://www.education.vic.gov.au/school/principals/spag/curriculum/Page s/wellbeing.aspx

7. Jordan, R., Jones, G. and Murray, D. (1998).DfES Publication (RR77) Educational interventions for children with Autism: A literature review of recent and current research. Birmingham: University of Birmingham.

8. NidhiSingal (2007), "Mapping the field of inclusive education: a review of the Indian literature", Published online: 20 Feb 2007, pp 331-350. https://doi.org/10.1080/13603110500138277

9. RomaneViennet and Beatriz Pont, "EDUCATION POLICY IMPLEMENTATION: A LITERATURE REVIEW AND PROPOSED FRAMEWORK", 2017, OECD Education Working Paper No. 162 Collins, D. (1998). 'Managing Truancy in Schools'. London: Cassell.

10. Reid, K. (1988). 'Combating School Absenteeism'. London: Hodder and Stoughton.

\section{AUTHORS PROFILE}

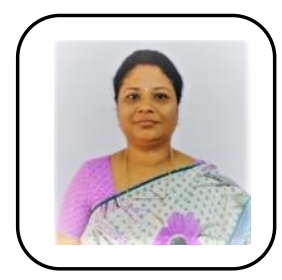

Dr. M. Kavitha, M.Com. MBA, M.Phil, Ph.D. is serving as an Assistant Professor in Guru Nanak College (Autonomous), Chennai and qualified SET in Commerce and SET in Management with 15 years of UG, 11 years of PG Teaching and research experience (Masters and Doctorate Level). Recognized Research Supervisor of University of Madras. Currently 7 candidates are pursuing their Ph.D. under her guidance. Evaluator of academic projects and trainer for FDP. She has experience in providing coaching for Soft skills and Personality development programmes for UG and
PG students. She is an Academic counsellor, Project Guide and Evaluator of IGNOU, Board of examiners of University of Madras and other universities and autonomous colleges. Executive Editor of Guru Nanak Journal of Multi-Disciplinary Research- special issues. To her credit she published more than 50 articles in reputed journals and conference volume proceedings, participated and presented several papers in many national and international conferences. She has successfully completed the ARPIT course of MHRD. She is a Women-in-charge of commerce department and Department Co- ordinator of IQAC . Organizing committee member of national and international conferences and serving as member in several committees and event organizer of various academic programmes.

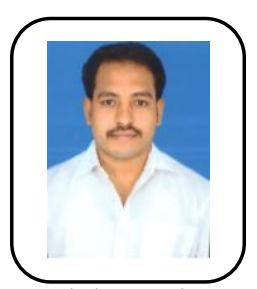

Mr. S. Naveen Kumar, is a Ph.D. Research Scholar pursuing his research under the guidance of Dr.M.Kavitha, Assistant Professor of Commerce in Guru Nanak College. His area of specialization is HRM. He completed his B.Com. at Alpha Arts \& Science college, Porur and his M.Com. Degree in Guru Nanak College. He presented his research papers in National and International Conferences. He published 6 research articles in reputed journals. He attended Two day workshop on "Thesis Writing", State level workshop on GST, One day workshop on "Tax planning and Tax filing" and "CSR \& companies Act 2013". He participated in many National and international conferences. 